\title{
Creating bonds, creating memories. Monasteries Kladruby and Opatovice in twelfth century and their forgeries
}

David Kalhous / kalha@centrum.cz

Ústav pomocných věd historických a archivnictví FF MU

\begin{abstract}
The twelfth-century forgeries for monasteries Kladruby and Opatovice in West- and East Bohemia are fascinating texts. These documents were written at the end of the eleventh century and in twelfth century. They recorded the beginnings of these monasteries in series of the deeds, and not in one single act, but all these deeds were in the second half of the twelfth century reshaped in one single document. As such, they are important sources for the establishment of the bonds between the central power and "periphery".
\end{abstract}

\section{Keywords}

diplomatics; Přemyslid realm; ecclesiastical history; history of power; networks local history; eleventh and twelfth centuries

This text was written thanks to the Lise-Meitner Project M 2120-G28 on Institute for Medieval Studies, Austrian Academy of Sciences, financed by FWF. 
In this paper, there will be discussed the deeds and charters and other documents that are connected with the early history of the Benedictine monasteries Opatovice and Kladruby. The pieces of pragmatic literacy created in the Přemyslid realm until 1200 are not very numerous. The case, where there are several documents issued for one person or institution, is even more rare. It seems, that this is not the case by the Benedictine monastery in Opatovice, as there is just one more extensive document allegedly issued for it. It provides us, however, with an important parallel to the forgery of the founding charter allegedly issued 1115 by Vladislav I for Benedictine monastery Kladruby, as both of these founding charters are assemblages of several documents that both reflect the growth of the landed property and incomes in time and their embeddedness within the region. Therefore, both documents are not only important from the perspective of the diplomatics, or paleography, but also from the perspective of the history of power (center/periphery). In this paper, both layers of analysis, auxiliary-historical and in social history, will support each other. Their combination will improve our understanding of the role of the ecclesiastical institutions and of the literacy they helped to introduce in the Czech lands by the establishment of the Přemyslid realm and of the social cohesion of the Bohemian society, as it will reveal concrete social mechanisms and tools used by the central power to cement its position within the social hierarchy.

\section{Opatovice and Kladruby (basic info)}

First, it will be necessary to introduce both of these ecclesiastical institutions. In the next step, the deeds created by them and charters issued for them before 1200 will be discussed in more detail regarding their paleography, style and structure. Third, the attention will be refocused on the establishment of the princely power in the regions. Finally, the role of the historical and cultural memory and their re-production via the charters will be scrutinized.

Let us start with the short introduction of above-mentioned monasteries. Opatovice was re-founded ca. 1073 during the reign of king Vratislav II of Bohemia (1061-1092) in East Bohemia near what is today Hradec Králové. Kladruby founded 1115 by Přemyslid prince Vladislav I (1109-1117, 1120-1125) we can find in West Bohemia approximately $40 \mathrm{~km}$ westwards from Plzeň-Pilsen. They both are monasteries situated in the regions hardly mentioned in the contemporary narrative sources - whereas Hradec was only remembered three times by Cosmas of Prague (†1125), Plzeň is noted just once in his chronicle. ${ }^{1}$

1 Kalhous, David: Mittelpunkte der Herrschaft und Cosmas von Prag. Zum Charakter der Macht des frühmittelalterlichen Fürsten. In: Praktische Funktion, gesellschaftliche Bedeutung und symbolischer Sinn der frühgeschichtlichen Zentralorte in Mitteleuropa. Ed by J. Macháček - Š. Ungermann. Bonn 2011, pp. 669-689, $670-672,674$. 


\section{Deeds connected with these monasteries in early Přemyslid era (until 1200)}

Now, we can characterize in more detail the deeds and charters issued for both of the monasteries.

\subsection{Sources}

\subsubsection{Opatovice}

I will start with the charters and deeds issued for Opatovice, because they are far less numerous.

\subsubsection{1 $\mathrm{Vr} \| \mathrm{Op} 1073^{2}$}

More important among them is the forgery issued allegedly 1073 by Vratislav II (1062-1092) as king of Bohemia, who, however, was anointed thirteen years later $1086 .{ }^{3}$ That signals a forgery. Václav Hrubý on one side made us aware of the fact, that the forgery for Opatovice repeated the phrases from Vladislav's II (1140-1172) charter for Hradisko issued $1160,{ }^{4}$ on the other side, he recognized that Vladislav's charter for Hradisko respected the style of other charters issued by Vladislav II (1140-1172). ${ }^{5}$ Therefore Hrubý came to the conclusion, there was originally Vladislav's charter for Opatovice that was used as a model for the existing forgery linked with his grandfather Vratislav II (1061-1092). Most probably there also existed a document (or series of documents) issued by Vratislav II and his noblemen, but we are not able to reconstruct its (or their) content and form anymore. ${ }^{6}$ The most convincing argument for the existence of such a privilege is the seal applied on Vr II Op 1073 that is identical with Vratislav's other seals. Although they are all spurious, their sameness is an indicia for the existence of a model, on which they were all based. ${ }^{7}$

2 Codex diplomaticus et epistolaris regni Bohemiae (= CDB) I. Ed. Gustav Friedrich. Pragae 1906-1907, pp. 368-369, nr. 386.

3 CDB I, pp. 368-371, nr. 386. It is now preserved in Oberösterreichisches Archiv Linz, Herrschaftsarchiv Freistadt as Uk. No. 1. Year 1088 as a year of monastery foundation is based on the fourteenth century chronicle, cf. Neplacha, opata opatovského, krátká kronika řimská a česká. In: Fontes rerum Bohemicarum (= FRB) III. Ed. J. Emler. Praha 1882, 468; Cf. Hrubý, Václav: Tři studie k české diplomatice. Ed. J. Šebánek. Brno 1936, pp. 131-132; Nový, Rostislav: Opatovická fundačni listina z r. 1073 CDB I.386. Nálezová zpráva. Československý časopis historický 8, 1960, pp. 894-895; Bistřický, Jan: Über Falsifikate böhmischer Gründungsurkunden bis zum Ende des 12. Jahrhunderts. Archivmitteilungen 4, 1991, pp. 186-187. For date of Vratislav's coronation cf. now an analysis of Reitinger, Lukáš: Vratislav. Prvni král Čechů. Praha 2017, pp. 99-105.

4 Cf. CDB I, pp. 194-197, nr. 208; Nohejlová-Prátová, Emanuela: Přiběhy kláštera Opatovického: příspěvek k vlastivědě země České. Praha 1925, p. 80 on the remark of V. Hrubý.

5 Hrubý, V.: Tři studie, p. 132. Cf. CDB I, pp. 204-206, nr. 227.

6 An attempt for its reconstruction was made by Hrubý, V.: Tři studie, pp. 133-138.

7 For its description cf. CDB I, p. 371, nr. 386. 


\subsubsection{Kochan}

Kochan's testament, on the other side, is interesting due to its form of preservation, we will discuss later. ${ }^{8}$ It does not include any date and can be dated only based on the paleography to the final decades of the twelfth century.

\subsubsection{Kladruby}

By Kladruby, the situation is more complicated as we have a group of relatively numerous forgeries issued for the monastery by the princes of Bohemia and a group of deeds connected with that monastery in less evident way.

\subsubsection{Deeds and charters issued for Kladruby}

\subsection{So II KI $1177^{9}$}

First, I will discuss the group of genuine documents. The oldest authentic charter for Kladruby (gift) was issued by Soběslav II (1173-1178) in February 1177 and it exists in two versions, older of which was written by the same hand that also wrote Soběslav's charter for Vyšehrad 1178. ${ }^{10}$ In both charters, in the Datum-per-manus formula is mentioned chancellor Gervasius, provost of the Vyšehrad chapter and we can therefore reasonably assume, they both were most probably produced by the princely chancellery.

Version A' of Soběslav's charter for Kladruby was, however, produced by its recipient by the end of the twelfth century. ${ }^{11}$

\subsubsection{2 ${\mathrm{VI} \mathrm{HKI} 1197^{12}}^{12}$}

Second genuine document for Kladruby was issued by Vladislav Henry. It is the confirmation of an older property transfer of the estate Bděněves from the local nobleman Zdislav to Kladruby, again preserved in original. Remarkable is that this transaction took place during the reign of abbot Berthold, i.e. after 1130, but before Apr-4 1131. ${ }^{13}$ It is

8 CDB I, p. 331, nr. 364. For linguistic analysis cf. Repp, Friedrich: Das Testament des Kochan. Wiener slawistisches Jahrbuch 9, 1962, pp. 78-82; Kalousek, Josef: Závět’ Kochanova. Český časopis historický 7, 1901, pp. 203-204.

9 CDB I, pp. 244-246, nr. 279; Národní archiv (= NA) Praha, Archivy českých klášterů zrušených za Josefa II. (1115-1760) (= AZK), ̌̌B Kladruby, inv. nr. 494; http://www.monasterium.net/mom/CZ-NA/ AZK | Kladruby/494/charter (accessed at 2016-11-28+01:00).

10 CDB I, p. 244, nr. 279; cf. CDB I, pp. 251-253, nr. 287. Cf. NA Praha, AZK, ŘB Kladruby, inv. nr. 494 and 495.

11 Cf. Šebánek, Jindřich: Einiges über Doppel- und Mehrausfertigungen von Urkunden. Folia diplomatica 2 , 1976, pp. 27-38, 31.

12 CDB I, pp. 330-331, nr. 363; NA Praha, AZK, ŘB Kladruby, inv. nr. 497, in: http://www.monasterium. net/mom/CZ-NA/AZK|Kladruby/497/charter (accessed at 2016-11-28+01:00); AZK, ŘB Kladruby, inv. num. 497. Cf. Wihoda, Martin: Vladislaus Henry. The Formation of the Moravian Identity. East Central and Eastern Europe in the Middle Ages, 450-1450, 33. Boston - Leiden 2015, p. 52, 59.

13 Novotný, Václav: Začátky kláštera Kladrubského a jeho nejstarši listiny. Praha 1932, p. 26. For date: Stutt- 
also noteworthy that this estate is not mentioned in the forgeries, we will discuss later, but only in Gregory-IX confirmation from 1234/1235. ${ }^{14}$

Apart from the above-mentioned genuine documents, there is also a large group of forgeries.

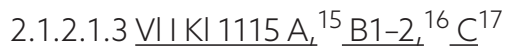

This extensive document was allegedly issued 1115 in the name of the prince Vladislav I (1109-1117, 1120-1125). It now exists in four copies, one of them (C) being from seventeenth century, whereas other three (A, B 1-2) were written during the second half of the twelfth century. Dalibor Havel confirmed the hand that wrote versions B1 and B2 was related to the hands that were originally active in the scriptorium of the monastery Hradisko near Olomouc ca. $1150 .{ }^{18}$ Though I didn't find any hint of stylistic similarities between Hradisko and Kladruby. Important for the chronology of the text preserved in this version of Vladislav's donation is:

1) that, on one side, the gift of the village Bděněves is not included in the list of further donations made by noble and free men from the neighborhood of the monastery that was appended to the description of the princely gift; ${ }^{19}$

2) but, on the other side, Vl I Kl 1115 B lists another transaction that took place during Berthold's abbacy. ${ }^{20}$

gart, Cod. hist. fol. 420, f. 24r (Necrologium Zwiefaltense). In: Monumenta Germaniae Historica (= MGH). Necrologia Germaniae I. Dioceses Augustensis, Constantiensis, Curiensis. Ed. F. L. Baumann. Berolini 1888, p. 249: Bertholdus n. c. abb. de Claderun, monachus noster, filius abbatis Heinrici; the year is only mentioned by seventeenth-century historian Sulger, Arsenius: Annales imperialis monasterii Zwifaltensis ordinis s. Benedicti in Suevia. Augsburg 1698, I. 22 (http://digital.wlb-stuttgart.de/sammlungen/sammlungsliste/ werksansicht/?no_cache=1\&tx_dlf[id]=3503\&tx_dlf[page]=24\&tx_dlf[double]=0\&cHash=db13eef61a2f084914 ffaa0394c80736 (accessed at 2016-11-29+01:00), p. 76: [...] sed postquam brevi tempore inter gravia ferocis populi discrimina multa pro ordine agendo et sustinendo fuit perpessus, ad superos abiit 4 Aprilis Anno 1131. About him cf. Herding, Otto: Arsenius Sulger (1644-1691) und seine Annalen von Kloster Zwiefalten. In: Herding, Otto: Beiträge zur südwestdeutschen Historiographie. Veröffentlichungen der Kommission für geschichtliche Landeskunde in Baden-Württemberg B 162. Ed. D. Mertens - H. Schwarzmaier. Stuttgart 2005, pp. 71-79.

14 CDB III-1. Ed. Gustav Friedrich. Pragae 1942, p. 118, nr. 101 (Nov. 1234-Ian. 1235).

15 CDB I, pp. 393-403, nr. 390; NA Praha, AZK, ŘB Kladruby, inv. nr. 492, in: http://monasterium.net/ mom/CZ-NA/AZK\%7CKladruby/492/charter (accessed at 2016-11-28+01:00).

16 B1: NA Praha, AZK, ̌̌B Kladruby, inv. nr. 493, in: http://www.monasterium.net/mom/CZ-NA/ AZK|Kladruby/493/charter (accessed at 2016-11-28+01:00); B2: Archiv Národního muzea Praha, Listiny, inv. nr. 3).

17 NA Praha, AZK, ŘB Kladruby, ms. 38/I (Liber privilegiorum monasterii Cladrubensis (= Lib. Cladr.)), fol. 1-16; ibidem, ms. 40/III, pag. 1-15.

18 Havel, Dalibor: Počátky latinské písemné kultury v českých zemích. Nejstarši latinské rukopisy a zlomky v Čechách a na Moravě. Brno 2018, pp. 380-381, 455-459. Cf. Dušková, Sáša: Studie k českému diplomatář 2. Listiny kladrubské. Sborník prací Filosofické fakulty brněnské university 2, 1954, pp. 285-307, here p. 298, nr. 2-4; Jagošová, Anna: Diplomata Bohemiae et Moraviae antiquissima. Prolegomena k CDB I. Brno 2015 (Ph.D. Thesis, Dept. of Auxiliary Historical Sciences and Archive Studies, FF MU), p. 139 calls it "monumental/demonstrative copy".

19 Cf. nr. 9.

20 CDB I, pp. 401-402, nr. 390: In loco Hochauihc c u $m$ a b b a te B e r to l d o cambivit Hainoicvs Ketlich 
Both of these indicia lead to the conclusion that the dispositive section in Vl I Kl 1115 $\mathrm{B}$ was in its nowadays form written soon after $1130 .{ }^{21}$

The versions B1 and B2 were followed by the version A corroborated by a forged seal of which avers was modeled after the seal of Vladislaus Henry (1197) from 1197, and of which revers imitated the seal of Frederick I from 1186 respectively. ${ }^{22}$ According to Anna Jagošová, it was a result of the revision of the monastery properties in the first third of the thirteenth century. ${ }^{23}$

\subsubsection{4 ${\underline{\mathrm{Fr} \mathrm{I} \mathrm{KI} 1183^{24}}}^{403}$}

Forgery allegedly issued 1183 by the prince Frederick I (1172-1173, 1178-1189) is only recorded in seventeenth-century cartulary. ${ }^{25}$ It should have been sealed by the prince Frederick and by the Bishop of Prague Jindřich Břetislav. ${ }^{26}$

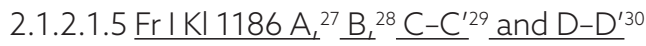

Even though the handwriting of the version A of the charter issued by the prince Friedrich I 1186 is not comparable to the script of the charter V1 I 1115 B (gothic minuscle), at least its layout with the text written in two columns still reminds on it. ${ }^{31}$ Both texts - Vl I Kl 1115 and Fr I Kl 1186 (in their different versions) - also show remarkable textual parallels. On Fr I 1186 A was applied a false seal of the prince Frederick I. ${ }^{32}$ Anna Jagošová is, however, of the meaning that there was a real charter issued by Frederick $I^{33}$

villam Turane sub tempore ducis Zobezlai sub testimonio horum virorum: Lupoldi fillii Borivoy et Mladote et Lutobor et Diuis et Zmil camerarii et Gredebor cum fatre Vacemil et Vto de Radispona et Paulic et Lutomericensium primatum: Cazlau, Martin, Milgozt. Superscriptio autem manu Iurate cancellarii ducis Uobezlai et confirmatio camerarii Petri. These witnesses are only named in the documents related to Kladruby from the third of the twelfth century. According to Dušková, S.: Studie, pp. 293-294 it is due to later interpolations.

Cf. Novotný, V.: Začátky, pp. 33-50.

Cf. also Křečková, Jitka: Falzum pečeti knižete Vladislava I. u zakládaci listiny kladrubského kláštera. In: Inter laurum et olivam. Acta Universitatis Carolinae. Philosophica et historica 2002. 1/2. Z pomocných věd historických 16. Praha 2007, pp. 177-183.

NA Praha, AZK, ŘB Kladruby, ms. 38/I (Lib. Cladr.), fol. 20v-22v; ib., ms. 40/III, pag. 19-21. CDB I, p. 422, nr. 403.

CDB I, p. 425-438, nr. 405; NA Praha, AZK, ŘB Kladruby, inv. nr. 496, in: http://www.monasterium. net/mom/CZ-NA/AZK|Kladruby/496/charter (accessed at 2016-11-28+01:00). Cf. NA Praha, AZK, ŘB Kladruby, ms. 38/I (Lib. Cladr.), fol. 23-26v, num. 7, fol. 33v-37v, nr. 10; ibidem, ms. 40/III, pag. 22-26 (E, E'). Ibidem, ms. 40/III, pag. 31-34. Ibidem, ms. 38/I (Lib. Cladr.), fol. 37v-42, num. II; ib., ms. 40/III, pag. 34-38. Ibidem, ms. 38/I (Lib. Cladr.), fol. 27-32, nr. 8; ib., ms. 40/III, pag. 26-31. Cf. also Dušková, S.: Studie, pp. 292-298 for villages Čečkovice, Tuřany, Trnové a Tisové . 


\subsubsection{6 $\mathrm{Fr} \mid \mathrm{KI} 1178$ ?, $\mathrm{B}, \mathrm{B}^{\prime}$}

That last charter issued for Kladruby before 1200 is also forgery preserved in the seventeenth century copy. ${ }^{34}$

\subsubsection{Deeds of the local noblemen ${ }^{35}$}

There is also a pair of deeds that were not directly issued for or by the monastery Kladruby. Though they were recorded in the ms. B XVI 2, National library in Prague that once belonged to it. Jiří Pražák also noted that one of the hands (B) that wrote that manuscript shares some characteristics with the handwriting of the charters $\mathrm{Vl}$ I Kl 1115 B2, Fr I Kl 1186 and Př O I Kl 1212 (?). ${ }^{36}$ These characteristics signal that all these documents were produced in Kladruby. With this being said, we have to modify the conclusion of Sáša Dušková that there was no chancellery in Kladruby - whereas in literary sense of the word she was right and the monks in Kladruby neither developed firm formulary, nor did they used diplomatic minuscule, ${ }^{37}$ the monastery still was able to provide its neighbors with help, once they needed to record their transactions and keep these records in safety.

\subsection{Hartman of Mírkov and his transaction $^{38}$}

First of these deeds was issued by Hartman of Mírkov who was probably related to Herman of Mírkov, known from Fr I Kl 1186, where he, Herman, sold half of the village Hostětice to the monastery. ${ }^{39}$ The above-mentioned deed, however, only records an exchange between Hartman and the sons of Zlavik.

\subsection{Beneda's daughter and her "vzdánie" 40}

Also the witnesses known from second deed were related to the monastery. The most important of them was Beneda - probably identical with the local nobleman Beneda of Svojšín - who testified in several charters issued in the last quarter of the twelfth c., two of them for Kladruby. ${ }^{41}$ Yet, even that transaction has directly nothing common with the monastery.

34 CDB I, p. 442-443, nr. 409; NA Praha, AZK, ŘB Kladruby, ms. 38/I (Lib. Cladr.), fol. 32-33; ib., ms. 40/ III, pag. 21 sq.

35 CDB I, p. 327, nr. 268; Pražák, Jiří: Ke kritice českých aktů XII. století. Sborník archivních prací 8, 1958, pp. $130-151$.

36 Ibidem, p. 145. Cf. CDB I, pp. 393-403, nr. 390; CDB II. Ed. Gustav Friedrich. Pragae 1912, p. 398, nr. 366.

37 Dušková, S.: Studie, pp. 297-298.

38 CDB I, p. 237, nr. 268 (1158-1166).

39 Pražák, J.: Ke kritice, p. 144.

40 Ibidem, pp. 130-151.

41 Ibidem, p. 144. Cf. CDB I, p. 246, nr. 279; p. 443, nr. 409; p. 244, nr. 278; p. 420, nr. 402; p. 320, nr. 355. The assumption of Pražák, J.: Ke kritice, p. 144 that his son-in-law Pavlík, husband of Beneda's daughter, 


\subsection{Structure}

In general, the role of the monastery in its surroundings is well imprinted in the structure of the "demonstrative copies" ${ }^{42}$ of above-mentioned founding charters, Vr II Op 1073 and Vl I Kl 1115 B.

\subsubsection{Opatovice}

In case of Opatovice (East Bohemia weakly represented in the contemporary texts), we are informed that there was originally a cell or hermitage founded and supported by local nobleman Mikulec. ${ }^{43}$ We are told that he decided to ask the prince for protection of his cell, which was already subjected to the Břevnov monastery near Prague, the foundation of the princely family. ${ }^{44}$ In the next step, Prince Vratislav II of Bohemia (1061-1092) should have appointed his chaplain Andrew with the office of abbot and in presence of his brothers, princes Otto of Olomouc (1061-1087) and Conrad I of Znojmo (10611092) and Jaromír-Gebhard, bishop of Prague (1068-1090), and "all members of the elites" and with their consent decided to provide the newly promoted monastery with the immunity and with the confirmation of its carefully enumerated estates. ${ }^{45}$ Among them the notary recognized the estates given to the monastery by the prince and those ones donated by other important men. ${ }^{46}$ One of them was also Mikulec.

As there was additionally recorded another princely donation in that charter, it is more than clear that the monks from Opatovice compiled that forgery using a set of different memorial records. It also proves that the monastery became to be the focal point for local elites as it further received gifts from its abbot Boleradus, who gave it village Libčany, situated not far away from Opatovice, from provost in neighboring center Hradec (today Hradec Kralove) called Tezlin, from princely chaplain Geco who again seems to be endowed with the estates near Hradec (Platěnice), and last but not least from Usebor, who gave the monastery his village Lodín near Hradec Králové. ${ }^{47}$

might be identified with a witness recorded in a transaction between Hainricus Ketlich and monastery Kladruby during the reign of Soběslav I (1126-1140), is chronologicaly impossible. Cf. CDB I, p. 401-402 nr. 390 (B1/2).

Jagošová, A.: Diplomata, p. 139.

43 CDB I, p. 368-369, nr. 386. For the medieval settlement of that microregion cf. Bláha, Radek - Sigl, Jiři: Př́spěvek k osídleni Opatovic nad Labem ve 13. století. Praehistorica 33/1-2 (Sborník k 80. narozeninám Víta Vokolka), 2016, pp. 55-60; Smetánka, Zdeněk: Výzkum na prédklásterním ostrưvku v Opatovicích nad Labem. Archeologické rozhledy 19, 1967, pp. 471-477.

44 CDB I, p. 369, nr. 386. For the beginnings of Břevnov monastery cf. Šrámek, Josef: Co (ne)víme o raně středověkých dějinách brèvnouského kläštera - a jak s tím naložit? Časopis Matice moravské (= ČMM) 134, 2015, pp. 207-218; Kalhous, David: K otázce počátků břevnovského kläštera. ČMM 134, 2015, pp. 207-213.

CDB I, p. 369-370, nr. 386.

46 Ibidem, p. 370 , nr. 386.

47 Ibidem; cf. Nohejlová-Prátová, E.: Př̀běhy. 


\subsubsection{Kladruby}

Similar pattern we can follow in Kladruby, monastery situated near Plzeň (Pilsen) in Western Bohemia, region strongly underrepresented in the written evidence until 1200 , where princely foundation also attracted neighboring elites, but remained under the control of the princely family. ${ }^{48}$ Version B of the charter allegedly issued by Vladislav I (1109-1117, 1120-1125) names not less than 33 other mostly noble, but partially also ignoble benefactors of the monastery, ${ }^{49}$ among them unknown duke Svatopluk,,$^{50}$ or duke Děpold, who both were most probably members of the princely family. One of these transactions listed at the end is dated in the reign of prince Soběslav I (1126-1140)..$^{51}$

48 CDB I, pp. 400-401, nr. 390, vers. B. Cf. Novotný, V.: Začátky; Nováček, Karel and col.: Kladrubský klášter 1115-1421: osídleni - architektura - artefakty. Plzeň 2010, p. 127-142. Similar strategies were followed in many other regions of medieval Europe in different periods of time, cf. Innes, Mathew: State and Society in the Early Middle Ages. The Middle Rhine Valley, 400-900. Cambridge studies in medieval life and thought IV. 47. Cambridge 2005; Potts, Cassandra: Monastic Revival and Regional Identity in Early Normandy. Studies in the History of Medieval Religion XI. Woodbridge 1997. For paralels in the mother-monastery of Kladruby Zwiefalten cf. Wallach, Liutpold: Berthold of Zwiefalten's Chronicle. Traditio 13, 1957, p. 187-233, esp. 168-171.

49 CDB I, p. 397, nr. 390 B1+2: Wi l l a l m u s addidit patrimonium suum, quod fuit avi ipsius Pule, Ratbori, et cum pomerio. Ibidem, pp. 399-403, nr. $390 \mathrm{~B} 1+2$ : Hęc sunt autem, que fideles dei pro animabus dederunt: $V$ to $\quad$ c o mes dedit duas villas Ceckouici, Maleuici. D e po lt dedit in Domaselich locum ad habitandum et partum et arbustum et inter duas vias terram ad dimidium aratrum. $B$ ra $n$ is etiam dedit in villa Leschan terram ad unum aratrum et partem silve et piscinam; dedit etiam terram ad dimidium aratrum in villa Telcna; item dedit ugezd et piscinam in ea loco, qui dicitur Lenih. L u to r a d dedit terram ad aratrum in Scapc, quam fra ter $s u$ s postea cambivit similiter pro terra ad aratrum loco Unil. C a d a etiam dedit hereditatem suam post mortem suam: in Nechamihc dedit terram ad unum aratrum, in Chardic terram ad duo aratra. $H u$ a $l$ $p r e s b$ y e $r$ dedit similiter totam hereditatem suam, scilicet villa Glinen. $D$ o b r e h $c$ etiam dedit terram ad aratrum in proprietatem sancta Marie in villa Dragomisle. Idem $D$ o b re $h c$ dedit terram ad aratrum in villa, que vocatur Cohcber, et ea conditione, ut si filius eius voluerit abbati servire, serviat pro terra; et si noluerit abbati servire, solvat hospitalitatem et cetera. $N$ i c o a $l$ us dedit vgezd. $R$ a d o $m$ a quoque dedit suum vgezd. $Z u e-$ $b$ o $r$ etiam cum terra sua se tradidit. Zlatine $M$ o y $z l$ a $u$ dedit ad duo aratra. $B$ o l a ad unum aratrum Tuscoue. Ŏd a lricus c o m es dedit vgezd unum et insulam humuli in villa, que vocatur Goteseuihc. Maseuicih C r is a $n$ ad duo aratra. Z ir a Wsanicih totam villam. C r $i$ n $i n$ Neganiche totam villam. Wi l l a $r$ vgezd prahni. P r e s t a $n$ Bezemin dimidiam villam. Naceleue totam villam. Midlouarech ad duo aratra et tria vgezd. Nahosicih dimidia villa. Nastrezeue ad unum aratraum. Tahoue ad unum aratrum. Hochauicih cum abbate totum quicquid habuit $I z b$ u $\quad$ e $t \quad L$ u $i h$ e $t \quad R$ ob $b i$ et vgezd. In loco Hochauihc cum abbate Bertoldo cambivit $H$ a $i$ n o $i$ c v s $K$ e $t$ l $i$ c $h$ villam Turane sub tempore ducis Zobezlai sub testimonio horum virorum: Lupoldi fillii Borivoy et Mladote et Lutobor et Diuis et Zmil camerarii et Gredebor cum fatre Vacemil et Vto de Radispona et Paulic et Lutomericensium primatum: Cazlau, Martin, Milgozt. Superscriptio autem manu Iurate cancellarii ducis Uobezlai et confirmatio camerarii Petri. I a n c i c Te s $i k$ dedit Vgezd. M $i l g$ os $t$ rusticus Zimaticih debitor septem urnarum mellis. $C r$ a $z$ e $n$ Lescine ad unum aratrum. Cisicih $S t r$ a $s$ ad unum aratrum. B o g u h u a $l$ Buseuicih ad unum aratrum. Senadicih $S$ e $t$ e $h$ ad unum aratrum. Nechat dedit hortum. Zuatoplic dux Bonaticih ad unum aratrum. Zoyk cum filiis suis. Sdatam qui debet persolvere quinquaginta massas ferri. In Oztrou comparavimus terram ad unum aratrum sub testimonio horum virorum: Marcuardi de Dubraua et Marcuardi de Vnil cum filio suo Zuba et Bernardi de Cernosicich. B e n e d a dedit totam terram, quam habuit in Ivnas. $Z$ b i g $n$ e u in Camenich dedit ad unum aratrum. Go $t p$ o $l d v s$ dedit villam Metelzco excepta una mansione. $C$ ŏ n o a d u s dedit ad quatuor aratra de suo vgezd. Cf. Important comments in Nováček, K. and col.: Kladrubský klášter, p. 135-140.

50 CDB I, p. 402, nr. 390 B1+2: Zuatoplic dux Bonaticih ad unum aratrum. Zoyk cum filiis suis. Sdatam qui debet persolvere quinquaginta massas ferri.

51 CDB I, p. 401, nr. 390: In loco Hochauihc cum abbate Bertoldo cambivit Ha $i$ n o $i$ c vs Ketlich 
The long list of the local benefactors of the monastery proves that the monastery Kladruby also became respected source of the salvation in the region that originally lacked the clearly recognisable control of the princely family. Its regional importance further support two deeds of the local lords who decided to have them archived in the monastery.

\section{Princely power in action? Culture of remembering}

\subsection{Building new memory with "old" words}

Although the above-mentioned genuine charters and forgeries include important insights into the historical memory of both of the monasteries, we should not oversee possible attempts to situate local story in wider context through the well-known Biblical allusions.

Whereas Lukas 14:33 played an important role in the discussions about the poverty ca. 1300, in Vladislav's charter for Kladruby (1115) the quotation is used in different meaning of the word: it is not the monks who should resign on worldly riches, but rather their secular supporters, to whom is given a chance to become true followers of Jesus Christ through the pious gift. ${ }^{52}$ These Biblical allusion should also have discouraged the local lords from harming monastic rights and properties. Therefore they were first threatened by eternal punishment and by the example of Julian the Apostate. ${ }^{53}$ It is again Lucas, who helps the notary to formulate an appeal on the donors, who will "But give as alms those things that are within, and behold, everything is clean for you". ${ }^{54}$ Bible also helps the notary to define proper conscience - it should be based on straightforwardness. ${ }^{55}$

villam Turane sub te mpore $d u c$ is $Z$ o b e z l a $i$ sub testimonio horum virorum: Lupoldi fillii Borivoy et Mladote et Lutobor et Diuis et Zmil camerarii et Gredebor cum fatre Vacemil et Vto de Radispona et Paulic et Lutomericensium primatum: Cazlau, Martin, Milgozt. Superscriptio autem m a n $u$ I u ra te c a n ce l l a ri $i$ d u c is U ob e zla $i$ et confirmatio camerarii Petri. Cf. nr. 21.

52 CDB I, p. 403, nr. 390 A: Quod si quis his aliquis aufferre presumpserit, m a le dictus sit a de o et a b o m n ibus sanctis e $i$ us, et mecum contendat in die iudicii habens partem cum Iuliano Apostata, qui occasione illius evangelice admonitionis: " $q u i \quad n$ o $n$ renunciaverit om nibus, quod poside[t, non potest meus esse discipulus"(Luk. 14:33), spoliabat cultores fidei et ecclesias dei. Cf. Roger I (1097) confirms the rights of the archbishopric in Cosensi (The Jews in Calabria. Ed. Cesare Colafemmina. 2012, p. 97, nr. 7): [...] decem libras auri purissimi sciat compositurum, atque sit maledictus et excommunicatus a Deo Patre Omnipotente et ab om nibus Sanctis e i u s; Chartae Galliae. Edition électronique 2014, no. 202528 (Telma). [En ligne] http://www.cn-telma. $\mathrm{fr} /$ chartae-galliae/charte202528/. Date de mise à jour: 16/09/11. Première version: 10 juin 2010: Quicumque haec quae supra praetitulavimus dissolvere voluerit, a Deo patre omnipotente, et sancta Dei genitrice Maria, et omnibus sanctis maledictus sit, et excommunicatus.

53 CDB I, p. 403, nr. 390 A: Quod si quis his aliquis aufferre presumpserit, m a le dictus sit a de o et ab o m n ibus sanctis e $i$ us, et mecum contendat in die iudicii habens partem cum Iuliano Apostata $[\ldots]$.

54 CDB I, p. 394, nr. 390 B/A: [...] credens nihil esse, quidquid dei non est, credens etiam illi, qui dicit: "D a t $e$ elemosinam et om nia munda sunt vobis" (Luk 11.41), et illi, qui dicit: "R ede mptio anime viri divicie sue" (Prov. 13. 8) [...]. CDB I, pp. 394-395, nr. 390 A: Hęc autem suntea, que in pura conscientia et in sim- 
Also following sentences are mixture of different hints and quotations, not necessarily inspired by Bible - apart from Commentaries of Augustine ${ }^{56}$ and hints on St. Wenceslas legend Crescente fide, ${ }^{57}$ we can also find quotations from well-known letter of pope Gelasius I about two powers in the world. ${ }^{58}$

For the group of charters connected with the reign of Vratislav II (1061-1092) seems to be characteristic the use of the Constantine's donation. In the forgery issued allegedly 1070 by Alexander II (1061-1073), but most probably produced in Bohemia, the quotations from that document helped to build the parallels between Vratislav II and Emperor Constantine.$^{59}$ It is not, however, the only case. Quotations from that documents were also identified in two other charters issued originally by Vratislav II (1061-1092). One of them is the forged foundation charter of the collegiate chapter in Stará Boleslav, which is now preserved in the eighteenth-century copy and which also identifies Vratislav's father Břetislav I (1034-1055) as its initiator and issuer, although the model

p l $i$ c $i$ t a t e cord $i$ s eidem ecclesie dedi sub testimonio Pragensis episcopi Hermanni et Morauiensis episcopi Iohannis et primatum terre absque omnis populi contradiction [...]. Cf. 2. Kor. 1. 12: Nam gloria nostra haec est: testimonium cons c i e n tia e nostrae, quod $i n$ s $i m p l i c i t$ a te cord $i s$ et sinceritate Dei, et non in sapientia carnali, sed in gratia Dei, conversati sumus in hoc mundo: abundantius autem ad vos.

56 CDB I, p. 394, nr. 390 A: [...] si rapina offeretur ei in holocaustum [...]. Cf. Augustinus Hipponensis, Quaestiones in Heptateuchum. In: Corpus scriptorum ecclesiasticorum latinorum XXVIII-3/3. Ed. J. Zycha. Pragae - Vindobonae - Lipsiae 1895, 3, 36, 26: [...] ut $i$ n ho lo c a us $t$ u $m$ offer re ntur [...]; ibidem, 3, 40, 37: [...] offeret agnum anniculum sine macula $i n$ ho loc a us t $\mathrm{m}$ et pullum columbinum pro peccato, id est pro peccato suo.

57 CDB I, p. 394, nr. 390 A: [...] quod nichil iniuste, nichil v $i$ cuiquam ablatum ei obtuli, $n$ i h $i$ l preter hoc, quod antecessoribus meis religiosis viris secundum consuetudinem terre offerre licuit. Cf. Crescente fide, bav. In: FRB I. Ed. J. Emler. Praha 1874, chap. 2, p. 184: Per vim atque per fraudem nulli hominum aliquid abstulit [...].

58 CDB I, p. 421, nr. 403: $D$ u o s u n t, quibus gracia succurente divina, universalis $r$ e $i t u r \quad m u n$ dus: sacerdotalis dignitas et regalis patrocinio quorum bonorum tueatur tranquillitas secundum deum et hominem et malorum reprimatur temeritas; quae divinum quoniam habuerunt initium, convenit, ut ecclesiarum utilitatibus, quarum deus ipse auctor et pater est, ante omnia invigilent studiosius et eius precipue honori deserviant, cuius auctoritate primitus sancita sunt. Cf. Schwartz, Eduard: Publizistische Sammlungen zum acacianischen Schisma. Abhandlungen der Bayerischen Akademie der Wissenschaften. Philosophish-historische Klasse, N.F. 10. München 1934; Patrologia Latina LIX, 42a: D u o s u n $t$ quippe, imperator auguste, quibus principaliter $m$ u $n d$ u s hic $r$ e $g$ i $t$ u $r$, auctoritas sacrata pontificum et $r$ e $g$ a $l$ is potestas, in quibus tanto gravius pondus est sacerdotum quanto etiam pro ipsis regibus hominum in divino reddituri sunt examine rationem. Nosti etenim, fili clementissime, quoniam licet praesedeas humano generi dignitate, rerum tamen praesulibus divinarum devotus colla summittis atque ab eis causas tuae salutis expetis hincque sumendis caelestibus sacramentis eisque, ut competit, disponendis, subdi te debere cognoscis religionis ordine potius quam praeesse, itaque inter haec illorum te pendere iudicio, non illos ad tuam velle redigi voluntatem. Cf. also Jonas d'Orléans: Le métier de roi. Ed. Alain Dubreucq. Paris 1995, chap. 1, p. 1 Unde Gelasius romanae ecclesiae venerabilis pontifex ad Anastasium imperatorem scribens: "Duae sunt, inquit, imperatrices augustae, quibus principaliter hic regitur mundus: auctoritas sacra pontificum et regalis potestas”.

59 Gründung der Kirche von Wischehrad, p. 253: [...] prefatus dux c ophinos terraronstatos du od ecim proprits humeris portas se videbatur. Locus ergo, in qua est erecta, Wissegrada cognominatur, quod sonat litteraliter: altior civitatibus. Qu a $\mathrm{m}$ s a c r os a n c t a m ecclesia $\mathrm{m}$ to tius provincie caput dici, venerari sanximus [...]; cf. MGH Fontes iuris Germanici antiqui in usum scholarum (=Fontes iuris) X. Constitutum Constantini. Ed. H. Fuhrmann. Hannoverae 1968, p. 84: [...] d u o d e c $i \mathrm{~m}$ nos sciatis de eius fundamentis secundum numerum duodecim apostolorum $c$ o $p h$ i n os terra on ustatos proprits asportasse humeris; quam sacrosanctam ecc les $i$ a $\mathrm{m}$ c a p ut et verticem omnium ecclesiarum in universo orbe terrarum dici, coli, venerari ac praedicari sancimus [...]. Cf. Reitinger, L.: Vratislav, for Vyšehrad-charter, or in this collection of articles. 
for existing forgery was originally produced in Vratislav's chancery. ${ }^{60}$ Second charter is the confirmation of the foundation charter for the monastery Hradisko by Olomouc. It was written 1078, but is, too, preserved in the sixteenth-century copy only. ${ }^{61}$ Both of these documents used malediction based on the Constitutum Constantini, yet, the charter for Hradisko takes over whole sentences, ${ }^{62}$ whereas the forgery for Stará Boleslav only quotes few phrases. ${ }^{63}$ As these quotations in the forgery for Stará Boleslav are not the same (concremandus suam cum Juda proditore/ concrematus cum diabolo), their notary(/ies)

60 Cf. Hrubý, V.: Tři studie, pp. 73-79.

61 CDB I, p. 85, nr. 80 mentions a record in seventeenth-century confirmation issued by Ferdinand III 1627. Thanks to Zaoral, Prokop: K zakládaci listině hradištského kláštera z roku 1078. ČsČH 16, 1968, pp. 275-283 we now register an earlier copy from the fifteenth century. Cf. also Dolista, Karel: Ještě k listinám hradištského kláštera z roku 1078. K článku P. Zaorala v Čš̌H roč. 16, 1968, s. 275-283. ČsČH 19, 1971, pp. 111-118.

62 CDB I, p. 86, nr. 80: [...] placita obclusione per apostolici iuris sibi attinentem dignitatem institutum o $b$ t e s $t$ a $m$ uro m nes nostros successores vel terrae primates et universum populum nunc et in posteris retro temporibus $n$ os $t$ ro principatui s $u$ b $i$ a $c$ e $n$ t em nulli eorum quoquo modo licere hec, $q u e \quad a \quad n o$ bis sanctione sanctecclesie concessa sunt, refringerevel in quoquam convelli. Si quis autem temerator huiusraiat contemptor extiterit, eternis condemnationibus subiaceat innodatus et sanctos dei, quorum reliquie ibidem requiescunt sibi in presenti et $i n$ futura vita sciat contrarios et in i nferno $i$ nfer $i$ or $i$ co n c re m a ndus suam cum Juda proditore portionem defleat perpetuo [...]. Cf. MGH Fontes iuris X. Constitutum Constantini, c. 19, pp. 95-96: [...] alia divalia decreta statuimus atque confirmavimus, usque in finem mundi illibata et inconcussa permanenda decernimus; unde coram deo vivo, qui nos regnare praecepit, et coram terribili eius iudicio o b t e $s$ t a $m u s$ per hoc nostrum imperialem constitutum o $m$ n $s$ nos tros successores imperatores vel cunctos optimates, satrapes etiam, amplissimum senatum et universum populum in toto orbe terrarum nunc et posterum cunctis retro temporibus imperio nos $t$ ro $s$ u $b i$ a c e $n$ t $i$, nulli eorum quoquo modo, haec, $q u$ a $e$ a nobis imperialis a nctione sacros a ncta $e$ Romanae e c c l e s $i$ a e vel eius omnibus pontificibus c o n c e s s a s u n t, refragare aut conf $r i n g$ e $e$ vel in quoquam convelli. Si quis a utem, quodnon credimus, in hocte merator aut contemptor extiterit, aeternis condemnationibus subiaceat in nodatus, et sanctos dei principes apostolorum Petrum et Paulum sibi $i n$ praesenti etf $u t u r a$ vita sentiat contrarios, atque in inferno inferiori concrematus, cum diabolo et omnibus deficiat impiis. For the influence of the Constitutio cf. Hugo Flaviniacensis, Chronicon I. In: MGH Scriptores VIII. Ed. G. H. Pertz. Hannoverae 1848, p. 301; Laehr, Gerhard: Die Konstantinische Schenkung in der abendländischen Literatur des Mittelalters bis zur Mitte des 14. Jahrhunderts. Historische Studien 166, Berlin 1926; Fuhrmann, Horst: Konstantinische Schenkung und abendländisches Kaisertum. Deutsches Archiv für Erforschung des Mittelalters 22, 1966, pp. 63-178; Fried, Johannes: Donation of Constantine and Constitutum Constantini. The Misinterpretation of a Fiction and its original Meaning. Millennium-Studien 3. Berlin 2007.

63 CDB I, p. 362, nr. 382: [...] et in futuro adversarios senciat atque $i$ n inferno $i$ nfe rioriconcremandus cum dyabolo et eius ministris nec non cum I uda traditore illisque, qui dixerunt domino deo: recede a nobis, scientiam viarum tuarum nolumus, redactus in nihilum deficiat impius. MGH Fontes iuris X. Constitutum Constantini, c. 19, p. 96: Si quis autem, quod non credimus, in hoc temerator aut contemptor extiterit, aeternis condemnationibus subiaceat innodatus, et sanctos dei principes apostolorum Petrum et Paulum sibi in praesenti et futura vita sentiat contrarios, atque $i n$ inferno inferioriconcre$m$ a tus, $c u m$ diabolo et omnibus deficiat impiis; for contemporary parallels cf. the foundation charter of the Virgin-Mary monastery (1052) by king Garcia VI, cf. Fidel Fita: Santa María la Real de Nájera. Estudio crítico. 1895; http://www.cervantesvirtual.com/portales/el_colegio_de_mexico/obra-visor-din/ santa-mara-la-real-de-njera-estudio-crtico-0/html/00ea54d2-82b2-11df-acc7-002185ce6064_35. html): [...] et sanctos dei, quorum reliquie ibidem requiescunt, sibi in presenti et in futura vita sciat contrarios et $i$ n inferno inferiori concremandus suam cum Juda proditore portionem defleat perpetuo. See also Colección diplomática medieval de la Rioja. Ed. I. R. de Lama. Logroño 1979, p. 359, nr. 82, where Alfons VIII confirms the gift of Alfons VI for the same monastery. 
must have had an independent access to the Constititutum Constantini. Small detail, where both charters agree with each other, ${ }^{64}$ is an indicia that confirms their common origin in the royal chancery. Both documents also enrich our knowledge about the texts available in the eleventh-century Czech lands. ${ }^{65}$

The analysis of the selected charters and deeds issued by the princes of Bohemia showed the interconnectedness of different genres of the literacy. It serves as an evidence that even the legal transactions might have been integrated with the world of providence and salvation. Yet, the notaries do not take over the quotation from the Bible (and from the other texts) blindly, they adapted them carefully and as we have seen by the quotation from Lukas 14:33, they might have completely changed their traditional exegesis. Although we need to be careful by their interpretation, as they might represent the memorized knowledge brought from abroad, they still contribute to our knowledge of the texts available in Czech lands in the eleventh and twelfth century.

\subsection{Memory in the manuscripts: Österreichische Nationalbibliothek, 395}

No historiographical manuscript from Kladruby survived until now, but there is an excellent example of such a manuscript from Opatovice. It was already mentioned that Kochan's testament was appended on the oldest historiographical manuscript connected with the Czech lands in general and with Opatovice in particular: Written by nine hands, ÖNB $395^{66}$ contains an Obituary probably of Prague's origin, but based on Halberstadt model, ${ }^{67}$ computus, the rules of the lives for canonries established by the Synod of Aachen 816, a History of Alexander the Great, the so called Annales Gradicenses et Opatovicenses based on Ekkehard of Aura and some Moravian tradition, ${ }^{68}$ and some other texts. These texts seem to be carefully selected and reflect not only the normative aspect of the monastic community, but due to the historiographic text fix it in the history of the salvation; similar role might have also played the obituary and computistic treatise. Part of that convolute was also a normative document, which defined ideal of the monastic life and which also confirmed the claims of the monastery, which were contextualized within the

64 CDB I, p. 86, nr. 80: [...]in inferno inferiori concremandus suam cum Juda prod $i$ to re portionem defleat perpetuo [...]; CDB I, p. 362, nr. 382: [...] in inferno inferiori c o n c remandus cum dyabolo et eius ministris nec non c um I uda traditore illisque, qui dixerunt domino deo: recede a nobis, scientiam viarum tuarum nolumus, redactus in nihilum deficiat impius.

65 Bláhová, Marie: Die mittelalterlichen Sammelhandschriften der historischen Texte in Böhmen. Studie o rukopisech 29, 1992, pp. 35-52.

66 Cf. Friedrich, Gustav: Památky umění písařského v Čechách a na Moravě. Praha 1904, pp. 12-13; Kernbach, Anna: Vincenciova a Jarlochova kronika v kontextu svého vzniku. K dějepisectví premyslovského období. Knižnice Matice moravské 28. Brno 2010, pp. 71-73, 240-244.

67 Graus, František: Necrologium Bohemicum - Martyrologium Pragense a stopy nekosmovského pojeti českých dějin. ČsČH 15, 1967, pp. 789-810.

68 Cf. Kalhous, David: Bohemi. Zu den Identitätsbildungsprozessen in Böhmen der Přemyslidenzeit (bis 1200). Forschungen zur Geschichte des Mittelalters 24. Wien 2018, pp. 130-131. 
story of the salvation through the local redaction of the world chronicle and combined obituary and martyrology.

\subsection{Memory in the space: Constructing friendly landscape}

Even though the attempts of the local lords to receive support of the ruler did not succeeded in every case,${ }^{69}$ church institutions were expected to provide them not just with the salvation, but also served as places where the contact between the regions was mediated, where the hierarchy among them was renegotiated (center and periphery), and where also the historical memory of Bohemi (and not just of the monastery) was kept and re-formulated from the local perspective. ${ }^{70}$ These mechanisms not only enhanced social cohesion of the local nobility, but also intensified communication between them and monarchic institutions and backed these local networks with sacral protection - certain role in this process also might have played texts. The charters and deeds played an important role in this complex network, as they, too, helped to temporarily fix this shared memory. Careful enumeration of the local supporters of the monastery visualized the social relations, gave them the legal form and placed them in the neighborhood of the prince-founder.

From the perspective of the paleography and diplomatics the discussed group of documents also clearly demonstrates the interconnectedness of the ecclesiastical institutions in the Czech lands.

\section{Vytváření vazeb a paměti. Kláštery Kladruby a Opatovice ve 12. století a jejich falza}

V této studii jsou analyzovány pragmatické písemnosti opatovického a kladrubského kláštera benediktinů vzniklé před r. 1200. Cílem je nejprve shrnout a revidovat stávající poznání o paleografické a stylistické stránce oněch písemností - zde platí primární zájem zejména analýze funkce citátů v textu, jež jsou rovněž cennou indicií ve sporu o autenticitu některých dokumentů. Tyto analýzy slouží jako východisko k zamyšlení nad rolí dokumentů církevních institucí v postupném budování monarchické moci v přemyslovských Čechách. Opatovice a Kladruby zde vystupují jako strážce paměti místních elit, jejich „výtah“ ke spáse a archiv, i jako jejich důležitý prostředník směrem k centru, ke knížecí moci.

69 For the in Czech historiography often discussed case of Mstis cf. Cosmas Pragensis, Chronica Boemorum, II. 19. In: MGH Scriptores rerum Germanicarum. Nova series II. Ed. B. Bretholz. Berolini 1923, p. 111; Kalhous, David: Anatomy of a Duchy. The Political and Ecclesiastical Structures of Early Přemyslid Bohemia. East Central and Eastern Europe in the Middle Ages, 450-1450, 19. Leiden - Boston 2012, pp. 129-131.

70 For local copies of Cosmas Chronicle cf. Kalhous, D.: Bohemi, p. 127-130, or idem: The piece that fitted to different puzzles. Chronicle of Cosmas Pragensis (ca. 1120) and its manuscript context (forthcomming). 